Endowment Task Force. Donations from the following people, made in response to an appeal this past spring from the Task Force, provided the funds needed to endow the award.

$\begin{array}{ll}\text { Samuel H. Barnes } & \text { Donald R. Matthews } \\ \text { Thad L. Beyle } & \text { John F. Miller } \\ \text { Fred G. Burke } & \text { Warren E. Miller } \\ \text { Karl H. Cerny } & \text { Burton B. Moyer, Jr. } \\ \text { Carl Q. Christol } & \text { Walter F. Murphy } \\ \text { William Y. Chuko } & \text { Stuart Nagel } \\ \text { Bernard C. Cohen } & \text { Dalmas H. Nelson } \\ \text { Weldon Cooper } & \text { Grady Harrison Nunn } \\ \text { Paul T. David } & \text { Robert A. Packenham } \\ \text { B. Vincent Davis, Jr. } & \text { Thomas Payne } \\ \text { Heinz Eulau } & \text { Suzanne Toll Peltason } \\ \text { David S. Fellman } & \text { Nelson W. Polsby } \\ \text { H. Schuyler Foster } & \text { Henry J. Pratt } \\ \text { Stanley T. Gabis } & \text { C. Herman Pritchett } \\ \text { Henry C. Galant } & \text { J. Austin Ranney } \\ \text { Herbert Garfinkel } & \text { Ross Rice } \\ \text { Ralph M. Goldman } & \text { Richard Rose } \\ \text { Esther S. Goldstein } & \text { Alan Rosenthal } \\ \text { Henry F. Goodnow } & \text { Stanley Rothman } \\ \text { Harold F. Gosnell } & \text { Francis E. Rourke } \\ \text { Doris Graber } & \text { Robert Scigliano } \\ \text { Fred I. Greenstein } & \text { Harold Seidman } \\ \text { Luther Gulick } & \text { Roberta Sigel } \\ \text { John Hazard } & \text { Dorothea P. Simon } \\ \text { Ferrel Heady } & \text { Herbert A. Simon } \\ \text { Alexander Heard } & \text { Rex J. Swartz } \\ \text { Pendleton Herring } & \text { Richard N. Swift } \\ \text { Samuel P. Huntington } & \text { Ross Talbot } \\ \text { Marian D. Irish } & \text { David B. Truman } \\ \text { Charles O. Jones } & \text { Vernon Van Dyke } \\ \text { Max M. Kampelman } & \text { A.J. “Jack” Wann } \\ \text { David C. Knapp } & \text { Myron Weiner } \\ \text { Peter J. Kosiba } & \text { James Q. Wilson } \\ \text { Howard Lentner } & \text { Frederick M. Wirt } \\ \text { David M. Levitan } & \text { Deil S. Wright } \\ \text { Arend Lijphart } & \text { K. E. Womack, Jr. } \\ \text { Madelon M. Loucks } & \text { Sidney Verba } \\ & \\ & \end{array}$

The Charles E. Merriam Award is given ". . . to the person whose published work and career represent a significant contribution "to the art of government through the application of social science research'."

Charles Merriam's career in the first half of this century exemplified this combination of innovative political and social science scholarship, and practical service to community and nation. The department he chaired in the $1920 \mathrm{~s}-40$ s set the agenda of the political science profession in the post-World War II decades. He was the key figure in the founding of the Social Science Research Council and its chair in its first decades. His public service included membership in the Chicago City Council, on President Hoover's Recent Social Trends Commission, President Franklin Roosevelt's National Resources Planning Board, and the Committee on Administrative Management.

The Merriam Award recipients from 1975 through 1987 were

Aaron Wildavsky, 1975

Alice M. Rivlin, 1976

James Q. Wilson, 1977

Don K. Price, 1978

E. Pendleton Herring, 1979

Evron M. Kirkpatric, 1980

Harold F. Gosnell, 1981

Richard E. Neustadt, 1982

Jack Peltason, 1983

George F. Kennan, 1984

James L. Sundquist, 1985

Thomas Cronin, 1986

Richard Nathan, 1987

A Merriam Award honoree will be announced at the 1995 Annual Meeting in Chicago. Nominations can be sent to the Selection Committee members, who are Twiley Barker, University of Illinois, Chicago, Chair; John Kingdon, University of Michigan; and Jack Levy, Rutgers University.

\section{Jones Selects Finifter As APSR Editor}

President Charles O. Jones has selected Ada W. Finifter, professor at Michigan State University, to become the next Managing Editor of the American Political Science Review. Finifter will succeed Bingham Powell, Jr., pending approval by APSA's Council at its August 31 meeting.

Finifter's term is scheduled to begin in the summer of 1995, at which time she will begin receiving submissions. Powell's last issue will be December 1995 .

Jones was guided in his choice of Finifter by a search committee chaired by President-Elect Sidney Verba. The other members of the committee included Leon Epstein, University of Wisconsin-Madison; Jean Bethke Elshtain, Vanderbilt University; John Hibbing, University of Nebraska; Matthew Holden, University of Virginia; Keith Kreh- biel, Stanford University; Powell, University of Rochester; Kay Schlozman, Boston College; and Jones (ex officio), University of Wisconsin-Madison.

The committee began its work by soliciting nominations for Managing Editor throughout the profession. A group of finalists was invited to write a letter to the committee indicating interest in the position and describing how he or she would handle the editorship. Six scholars responded.

The search committee was sufficiently impressed by the ideas articulated by the finalists that they asked APSA staff to extract portions of the letters from each and pass them on to whoever became editor. Verba and Jones, reflecting the consensus of the committee, expressed confidence in the ability of each of the finalists to edit the Review capably and fairly.

"I have tremendous confidence in Ada Finifter," Jones said in announcing his choice. "In addition to her demonstrated managerial and editorial skills, she has the admirable quality of caring deeply about the profession. The Review is in good hands, as it has been with the fine service of Bing Powell."

Finifter is editor of the widely read Political Science: State of the Discipline (1983) and the completely new volume Political Science: State of the Discipline II (1993). The articles from the first book originated from specially commissioned papers at the 1982 Annual Meeting on the state of the discipline under her direction as Program Chair.

Finifter is a scholar of American government and politics, and comparative public opinion, electoral behavior and political psychology. She is well known for her work on political alienation. Her most recent $A P S R$ article, "Redefining the Political System of the USSR: Mass Support for Political Change," appeared in December 1992 (coauthored with Ellen Mickiewicz).

A former President of the Midwest Political Science Association, Finifter has served the profession in many positions, including APSA Annual Meeting Program Chair, Chair of APSA's Committee on 
Professional Ethics, member of APSA's Council, and APSA VicePresident. She has also served on the Program Committee of the International Political Science Association and on the Executive Council of the Inter-university Consortium of Political and Social Research.

Finifter is a former Congressional Fellow and Fulbright Senior Scholar, as well as a recipient of major grants from the Russell Sage Foundation and the National Science Foundation. She has served on the editorial boards of six scholarly journals, including that of the APSR from 1976 through 1981.

\section{Lichbach Named Book Review Editor}

Mark Lichbach, professor at the University of Colorado-Boulder, has been named Book Review Editor of the American Political Science Review by Managing Editor Bingham Powell, Jr. Lichbach will replace Melissa Collie of the University of Texas whose three-year term is concluding.

Lichbach will begin receiving books on September 1 while Collie will complete reviews currently underway. Her last issue will be the March 1995 APSR.

Lichbach's initial term will be one year to coincide with the last year of Powell's overall editorship.

The Book Review of the APSR constitutes the only comprehensive publication of book reviews in political science. Under Collie's editorship this section of the APSR has expanded in number of books reviewed and page content.

Both Powell and Lichbach have expressed interest in sustaining the increased number of reviews and in expanding the multiple book review essays, as space permits.

\section{Council Lifts South Africa Ban}

On April 16 APSA's Council removed the provision in APSA's by-laws proscribing direct investments in South Africa.

The move occurred in the context of a request from African
National Congress leader Nelson Mandela to governments and organizations throughout the world to end such embargoes, especially in light of South Africa's new, more inclusive constitution and the imminent, democratic elections later in the month.

Treasurer Susan Bourque, on behalf of the Trust and Development Committee, which oversees APSA investments, asked the Council to delete all reference to South Africa in the by-laws. After some discussion, the Council unanimously agreed to lift the ban.

\section{Special Annual Meeting Fee To Introduce Community College Faculty to the APSA}

The Association has initiated an effort to serve and recruit political science community college faculty. This effort has been endorsed by the 1993 Program Assessment Committee, chaired by Richard F. Fenno, and the Education Committee, chaired by Paul Allen Beck. To introduce these faculty to the profession and the APSA, the Council has approved a registration fee of $\$ 25.00$ for non-APSA members who teach at community colleges for the 1994, 1995, and 1996 Annual Meetings.

A survey of community college political science faculty was conducted in fall 1993 by the Education Committee. The faculty who responded already have ties to the profession, albeit more often now to state and regional associations than to the APSA. These faculty teach in departments that share many attributes with social science and multidisciplinary departments in four-year colleges in faculty size and course loads. Indeed, community college faculty do not have heavier teaching loads-in the number of courses or course preparations-than do faculty in interdisciplinary undergraduate departments. Community college faculty do have different teaching assignments in types of courses. Three-fifths of the faculty reported teaching one or more courses in a cognate discipline (most often history) and nearly all of the political science courses are at the introductory level.

Over three-quarters of the community college political scientists who responded to the survey are interested in professional connections with college and university faculty. But, community college faculty believe that the two groups of faculty are very different or somewhat different. Nonetheless, since community colleges teach an increasing proportion of postsecondary students and half their political science students-according to the survey's respondents-go on to continue their education in colleges or universities-an APSA effort to better represent community college faculty could benefit students and possibly encourage more students to continue to take courses or major in the discipline.

\section{Association Establishes Graduate Fellowship Program for Native American Students}

The APSA Council has approved a graduate fellowship program for Native American students to complement the existing fellowship programs for African-American and Latino students. Its purpose is to help to identify and aid Native American students and to increase the number of Native Americans in the profession. The program will offer a stipend of $\$ 6,000$ per year for one student annually and identify other worthy students as unfunded fellows. As with the other APSA graduate fellowships, graduate schools will be encouraged to provide full funding to APSA Native American Fellowship winners, supplanting the APSA award.

In administering the program, eligibility will normally apply to Native Americans who are enrolled tribal members. Applicants must qualify for acceptance in departments of political science at accredited institutions of higher learning, and potential for success in graduate studies and financial need will be given major consideration in awards. Fellowship recipients must 